\title{
The effect of bean sprout waste and feeding time to the chemical composition of Garut lamb
}

\author{
Siti Aslimah $\left.{ }^{1 *}\right)$ Mohammad Yamin ${ }^{2)}$ and Dewi Apri Astuti ${ }^{3)}$ \\ 1) Program Studi Produksi Ternak, Politeknik Pertanian dan Peternakan Mapena, \\ ${ }^{2)}$ Departemen Ilmu Produksi dan Teknologi Peternakan, Fakultas Peternakan, \\ Institut Pertanian Bogor \\ ${ }^{3)}$ Departemen Ilmu Nutrisi dan Teknologi Pakan, Fakultas Peternakan, \\ Institut Pertanian Bogor,
}

Submitted: 08 March 2019, Accepted: 11 October 2019

\begin{abstract}
This research aims to determine the chemical composition of Garut lamb fed with bean sprout waste along with different feeding time. The subjects of this research were 12 Garut sheep aged 6 to 7 months with the initial weight at $16.76 \pm 2.09 \mathrm{~kg}$ (coefficient of variation $=12.47 \%$ ). Both of the given feed were consisted of $14 \%$ isoprotein and $65 \%$ iso-total digestible nutrients (iso-TDN), which divided into R1 (40\% forage $+60 \%$ concentrate 1) and R2 (40\% bean sprout waste $+60 \%$ concentrate 2 ). The research was conducted in a completely randomized design with $2 \times 2$ factorial and replicated 3 times. The first factor was two feed types (R1 and R2), while the second factor was the feeding time (morning and afternoon). The obtained chemical composition data of lamb were then analyzed with ANOVA. The results showed that the chemical composition of Garut lamb fed with bean sprout waste was similar to the lamb fed with forage. Moreover, the different feeding time did not show significant differences $(\mathrm{P}>0.05)$ as well, and there was no interaction between feed types and feeding time to the chemical composition of Garut lamb. The water, fat, protein, and ash content of Garut lamb fed with bean sprout waste were $77.09 \pm 2.07 \% ; 1.60 \pm 0.69 \%$; $16.66 \pm 0.38 \%$; and $0.42 \pm 0.41 \%$, while fed with forage were $73.25 \pm 1.66 \% ; 3.27 \pm 2.02 \% ; 17.68 \pm 1.82 \%$; and $0.48 \pm 0.20 \%$, respectively.
\end{abstract}

Keywords: lamb; meat chemical composition; bean sprout waste; feeding time.

${ }^{*}$ Corresponding Author: aslimah@mapena.ac.id 


\section{INTRODUCTION}

Sheep is one of the most important commodities in Indonesia as the livestock has a special role for Muslim people. However, its role in supplying national demand for meat is still low, which only fulfilled around $1.7 \%$ of national meat production (Directorate General of Livestock and Animal Health of Indonesia, 2012). The sheep productivity is affected by various factors, such as its genetic traits, environmental factors (temperature and relative humidity), and feeding management. Soeparno (2005) reported that the consumed feed, aside for body maintenance and production, will affect the chemical quality of the produced meat as well.

Indonesian farmers commonly feed low qualified natural forages for their livestock, thus resulted in low livestock productivity as well. Research by Astuti et al. (2011) showed that the average daily gain (ADG) of local sheep fed with forages is around 29-48 g/day. In addition, vegetable market wastes are also widely utilized as a feed alternative. One of the commonly utilized vegetable wastes for livestock feed is been sprout waste (BSW), which is an unconsumed derivative product in mung bean processing industry.

In terms of quality, BSW had good nutrient contents as it is originated from mung bean which is rich in nutrients. Ifafah et al. (2011) reported that dry BSW contained $13.63 \%$ crude protein, $49.44 \%$ crude fiber, and $64.65 \%$ total digestible nutrient (TDN). The relatively high fiber content in BSW showed the potential for BSW to substitute forage as livestock feed. The initial survey on BSW availability in Bogor Regency showed that BSW production reached 1.5 ton/day (Ifafah et al., 2011), while in DKI Jakarta reached 1.19 ton/day (Saenab and Retnani, 2011). Previous research on the utilization of BSW for livestock feed was done by Aslimah et al. (2014) which showed ADG at 141.29 g/day in sheep fattening. In addition, Rahayu et al., (2013) showed that the feeding of BSW resulted in $153.3 \mathrm{~g} /$ day in Garut sheep and $127 \mathrm{~g} /$ day in Javanese sheep.

The ideal temperature and humidity for tropical livestock according to Yousef (1985) is at $22-31^{\circ} \mathrm{C}$ and less than $75 \%$ humidity. The high temperature and relative humidity could disrupt livestock homeostatic condition in releasing body heat, thus resulted in increased body temperature and heat stress. In order to maintain its body temperature, the livestock will delay its metabolism process by decreasing its feed consumption and will eventually affect its growth (Yani and Purwanto, 2006). Suprayogi and Astuti (2005) added that the high temperature and humidity caused energy inefficiency, noting that the energy for body growth and production will be shifted for respiration.

The heat stress of the livestock is originated both from the environment or body metabolism. On the other hand, sheep are categorized as diurnal animal, which its main activity will be spent during daylight. Therefore, a strategy to determine feeding time should be done to avoid heat stress. The appropriate feeding management will prevent the occurrence of heat stress and improve livestock productivity and meat quality. Research on the utilization of BSW for feed-in sheep fattening has been previously done. However, research on lamb quality from BSW-fed sheep and its correlation on the environmental temperature is still limited. This research thus aims to determine the effect of BSW as forage substitute and its correlation to the feeding time in chemical quality of Garut lamb (water, protein, fat, and ash content).

\section{MATERIALS AND METHODS}

The research was conducted in the Laboratory of Small Ruminants, Faculty of Animal Science, IPB University. The chemical analysis is conducted in the PAU 
laboratory of IPB University. The subjects of this research were 12 Garut sheep aged 6 to 7 months with the initial weight at 16.76 $\pm 2.09 \mathrm{~kg}$ (coefficient of variation= $12.47 \%$ ). The research was conducted in a completely randomized design with $2 \times 2$ factorials and 3 replications. The first factor was different feed (R1 and R2), and the second factor was the different feeding time (morning and afternoon). Both of R1 and R2 contain $14 \%$ isoprotein and $65 \%$ iso-total digestible nutrients (iso-TDN) which can be seen in Table 2. Moreover, the R1 consisted of $40 \%$ forages and 60 concentrates 1 , while the R2 consisted of $40 \%$ BSW with $60 \%$ concentrate 2 . Both concentrates were given in the crumbled form, and the forage was collected from the Laboratory of Small Ruminants Pasture, Faculty of Animal Science, IPB University. The BSW was obtained in several bean sprout merchants across Bogor and Anyar market. The nutrient content and feed formulation in this research are presented in Table 1 and 2.

Table 1. Nutrient content of feed (100\% dry matter)

\begin{tabular}{lrrrrrrrr}
\hline \multirow{2}{*}{ Feedstuff } & Ash & \multicolumn{1}{c}{ CP } & CF & CFT & NFE & Ca & P & TDN \\
& & & ------------ & \\
\hline Bean sprout waste & 2.81 & 13.76 & 30.14 & 0.43 & 52.87 & 0.91 & 0.27 & 70.23 \\
Concentrate 1 & 14.57 & 14.17 & 25.97 & 1.73 & 43.57 & 1.46 & 0.54 & 62.95 \\
Forage & 7.58 & 9.56 & 23,61 & 0.82 & 58.43 & 0.33 & 0,19 & 68.39 \\
Concentrate 2 & 14.29 & 16.35 & 27.26 & 1.42 & 40.28 & 1.48 & 0.56 & 62.10 \\
\hline
\end{tabular}

Description: $\mathrm{CP}=$ crude protein; $\mathrm{CF}=$ crude fiber; $\mathrm{CFT}=$ crude fat, NFE = nitrogen-free extract, $\mathrm{Ca}=$ calcium, $\mathrm{P}=$ phosphorus, $\mathrm{TDN}=$ total digestible nutrient.

Table 2. Composition and nutrient content of feed formulation

\begin{tabular}{lcc}
\hline \multicolumn{1}{c}{ Description } & $\mathrm{R} 1$ & $\mathrm{R} 2$ \\
\hline Feedstuff ${ }^{*}(\%)$ & 40 & 0 \\
Forage & 0 & 40 \\
Bean sprout waste & 27 & \\
Concentrate & 14 & 28.5 \\
$\quad$ Cassava waste & 13 & 14.5 \\
Palm kernel meal & 5 & 11 \\
Soybean meal & 0.2 & 5 \\
Molasses & 0.3 & 0.2 \\
CaCO3 & 0.3 & 0.3 \\
Ca3(PO4)2 & 0.2 & 0.3 \\
NaCl & & 0.2 \\
Premix & 11.60 & \\
Ration nutrient composition $(\%)$ & 13.63 & 9.86 \\
Ash & 25.80 & 14.00 \\
Crude protein & 1.18 & 27.64 \\
Crude fiber & 47.54 & 1.21 \\
Crude fat & 64.62 & 47.29 \\
Nitrogen free extract & 65.86 \\
Total digestible nutrient & & \\
\hline
\end{tabular}

Description: ${ }^{*}$ Feed composition based on $100 \%$ dry matter. R1 (40\% forage $+60 \%$ concentrate 1) dan $\mathrm{R} 2$ ( $40 \%$ bean sprouts waste $+60 \%$ concentrate 2$)$. 
Two weeks environmental and feeding adaptation was performed prior to data collection to accustom the sheep in consuming feed treatment. The sheep were then reared according to the research treatment for 3 months. The sheep were fed in the morning at $06.00 \mathrm{am}$, or in the afternoon at $18.00 \mathrm{pm}$ according to the feeding time treatment, and the drink was given ad libitum, while the feed leftovers were weighted in the following day. The observation was done at $06.00-08.00 \mathrm{am}$ for morning feeding and at 18.00-06.00 for afternoon feeding. The feed consumption data was obtained by measuring the difference between the amount of given feed and the leftovers. The nutrient consumption was measured by multiplying the result of proximate analysis with consumed feed (AOAC, 1995).

The sheep were slaughtered by following halal slaughtering method and not fed for 16 hours prior to the slaughter. The slaughtering was firstly done by cutting the neck area close to the lower jaw until the vein, esophagus and trachea were cut. The head was then separated by cutting the occipito-atlantis joints, and four legs were cut in the carpo-metacarpal joints (front legs) and tarso-metatarsal joints (hind legs). The rest of sheeps' body part was then hung on the tendo achilles part for skinning. The carcass was obtained after evisceration and then put in the chiller to be rested for 16 to 24 hours. After that, the carcass was cut into two parts by cutting along the backbone from the neck into sacral area in the rump area. The chemical analysis of lamb was done by using the left Longissimus dorsi cut as the sample. The chemical analysis consisted of water, ash, protein and fat content by following AOAC (2005). The feed consumption and chemical analysis data were then analyzed by GLM method (ANCOVA) and followed with least square mean (LSMEAN) test to determine the differences (Mattjik dan Sumertajaya, 2013).

\section{RESULTS AND DISCUSSION}

The average feed consumption in the form of dry matter (DM) and nutrients consumption are presented in Table 3 . The results showed that DM consumption was higher in sheep fed with BSW compared to the forage. The higher consumption is allegedly caused by the fresher aroma of BSW and added with more tender texture compared to the forage, thus resulted in higher palatability. According to Forbes and Mayes (2002), the feed palatability is affected by texture, physical form, flavor, aroma, and other factors. The higher BK consumption in $\mathrm{R} 2$ resulted in higher crude protein (CP) and crude fat (CF) consumption as well. However, the different feeding time did not significantly affect $(\mathrm{P}>0.05)$ the $\mathrm{DM}$ and nutrient $(\mathrm{CP}$ and $\mathrm{CF}$ ) consumption.

The chemical analysis of lamb in this research did not show any interaction between feeding time and feed types to the chemical qualities of the lamb, as well as each treatment individually. The chemical composition or nutrient content in meat, which includes water, fat, protein, and ash content is essential as each would determine the meat quality.

\section{Water Content}

The water content of Garut lamb in this research is around 72 to $78 \%$. Moreover, the result showed that the different feed types and feeding time did not show significant differences. According to Anggorodi (1994) and Tillman et al. (1998), feed nutrients and livestock age would significantly affect water content in meat. The similar water content of lamb in this research is allegedly due to the post-puberty growth phase of the sheep. The presumption is in line with Soeparno (2005) who stated that water, fat, protein and ash content in meat will be constant during post-puberty phase. The water content of Garut lamb in this research is categorized as normal. Aberle et al. (2001) showed that the water content in meat is around 60 to $80 \%$. 
However, the result is higher compared to the finding by Suparno et al. (2009) which showed the average lamb meat fed with 16.29 to $20.88 \% \mathrm{CP}$ and 62.56 to $67.31 \%$ TDN was around 73.124 to $75.538 \%$.
Aberle et al. (2001) added that the species, sex, age, feed, and farming location would affect water content in lamb. The average chemical compositions of Garut lamb in this research is presented in Table 4 as follows:

Table 3. Feed consumption with different type and feeding time

\begin{tabular}{llccc}
\hline \multirow{2}{*}{$\begin{array}{l}\text { Parameter } \\
\text { (g/head/day) }\end{array}$} & Feed & \multicolumn{2}{c}{ Feeding Time } & \multirow{2}{*}{ Average } \\
\cline { 3 - 4 } Dry Matter & R1 & $760.31 \pm 121.97$ & $641.18 \pm 73.18$ & $700.74 \pm 111.13^{\mathrm{b}}$ \\
& R2 & $1023.5 \pm 36.68$ & $1018.19 \pm 88.71$ & $1020.85 \pm 60.78^{\mathrm{a}}$ \\
& Average & $891.91 \pm 165.14$ & $829.68 \pm 218.93$ & \\
Crude Protein & R1 & $96.37 \pm 1.64$ & $91.34 \pm 10.85$ & $93.86 \pm 7.46^{\mathrm{b}}$ \\
& R2 & $141.34 \pm 3.14$ & $142.16 \pm 12.36$ & $141.75 \pm 8.08^{\mathrm{a}}$ \\
& Average & $118.86 \pm 24.73$ & $116.75 \pm 29.71$ & \\
Crude Fat & R1 & $8.04 \pm 0.07$ & $7.63 \pm 0.95$ & $7.84 \pm 0.64^{\mathrm{b}}$ \\
& R2 & $11.11 \pm 0.29$ & $10.48 \pm 0.77$ & $10.79 \pm 0.62^{\mathrm{a}}$ \\
& Average & $9.58 \pm 1.69$ & $9.06 \pm 1.74$ & \\
\hline
\end{tabular}

Note: $\mathrm{R} 1=40 \%$ forage $+60 \%$ concentrate $1 ; \mathrm{R} 2=40 \%$ bean sprout waste $+60 \%$ concentrate 2. Different supersripts in the same row or column mean differ with significantly $(\mathrm{P}<0.01)$.

Table 4. Chemical composition of Garut lamb with different type and feeding time

\begin{tabular}{llccc}
\hline Parameter $(\%)$ & \multirow{2}{*}{ Feed } & \multicolumn{2}{c}{ Feeding Time } & \multirow{2}{*}{ Average } \\
\cline { 3 - 4 } Water & R1 & $75.97 \pm 2.13$ & $78.21 \pm 1.56$ & $77.09 \pm 2.07$ \\
& R2 & $72.15 \pm 0.79$ & $74.36 \pm 1.62$ & $73.25 \pm 1.66$ \\
\multirow{3}{*}{ Fat } & Average & $74.06 \pm 2.54$ & $76.28 \pm 2.55$ & \\
& R1 & $1.85 \pm 0.62$ & $1.35 \pm 0.80$ & $1.60 \pm 0.69$ \\
\multirow{2}{*}{ Protein } & R2 & $4.46 \pm 2.01$ & $2.08 \pm 1.39$ & $3.27 \pm 2.02$ \\
& Average & $3.16 \pm 1.95$ & $1.72 \pm 1.09$ & \\
\multirow{3}{*}{ Ash } & R1 & $16.84 \pm 0.20$ & $16.48 \pm 0.47$ & $16.66 \pm 0.38$ \\
& R2 & $17.52 \pm 1.64$ & $17.85 \pm 2.35$ & $17.68 \pm 1.82$ \\
& Average & $17.18 \pm 1.11$ & $17.16 \pm 1.70$ & \\
& R1 & $0.69 \pm 0.45$ & $0.15 \pm 0.10$ & $0.42 \pm 0.41$ \\
& R2 & $0.51 \pm 0.31$ & $0.45 \pm 0.07$ & $0.48 \pm 0.20$ \\
\hline
\end{tabular}

Note: $\mathrm{R} 1=40 \%$ forage $+60 \%$ concentrate $1 ; \mathrm{R} 2=40 \%$ bean sprout waste $+60 \%$ concentrate 2 .

\section{Fat Content}

The fat content of Garut lamb in this research is around 1.60 to $4.46 \%$. Moreover, the chemical analysis of Garut lamb in this research is in accordance with Aberle et al. (2001) who reported that there was a negative correlation between fat content and water content in meat. In Table 4 , it can be seen that the lowest fat content in R1 $(1.60 \pm 0.69 \%)$ had the highest water content $(77.09 \pm 2.07 \%)$, even though did not show any differences with R2. The fat content in Garut lamb in this research did not show any differences even though the $\mathrm{CF}$ consumption was different $(\mathrm{P}<0.01)$. The result is allegedly caused by the relatively young age of the sheep, so the fat deposition in fat was not intensive. Aberle 
et al. (2001) reported that adipose is the last developed tissue after bone, nerves, and muscle. The amount of fat in meat would affect water content as the compounds would enable looseness in meat microstructure and water binding by protein.

Meat fat is an important component in sensory assessment, as it would affect the meat flavor. However, some consumers prefer lower fat content due to the health issue from cholesterols. Hence, the result of this research would be preferred by those consumers. The fat content of Garut lamb in this research is similar to finding by Cloete et al. (2012) which showed 3.43 to $3.64 \%$ of fat content of lamb from different breed. However, the result is lower compared to the finding by Purbowati et al. (2006) which showed that fat content of lamb from local breed at the age of 1.5 to 12 months is around 3.96 to $5.08 \%$.

\section{Protein Content}

The protein content analysis of sheep fed with $40 \%$ BSW (R2) did not show significant differences ( $\mathrm{P}>0.05)$ compared to forage feeding at the same percentage (R1), even though the CP consumption was different. The $\mathrm{CF}$ consumption in $\mathrm{R} 2$ was at $141.75 \pm 8.08 \mathrm{~g} /$ day, while in $\mathrm{R} 1$ was at $93.86 \pm 7.46 \mathrm{~g} /$ day. The finding is in accordance with Tilman et al. (1998) which showed that the protein content in lamb will be relatively constant and not affected by nutrient consumption and age of the sheep. Protein makes up the highest dry matter component in lamb, with almost $50 \%$ of the animals' dry weight is consisted of protein. The protein content of lamb in R1 and R2 were $16.66 \pm 0.38 \%$ and $17.68 \pm 1.82 \%$, respectively, with the average at $16.48 \pm$ 0.47 to $17.85 \pm 2.35 \%$. The protein content of Garut lamb in this research is categorized as normal. Aberle et al. (2001) showed that the average protein content in lamb is around 16 to $22 \%$, while Purbowati et al. (2006) reported higher protein content in lamb from local breed, which is around
$17.83 \%$ to $20.06 \%$. Moreover, Cloete et al. (2012) reported that the protein content of Dorper lamb reared under the intensive farming system is $23.1 \%$. In addition, research by Falahudin and Imanudin (2018) showed that protein content in lamb from local breed fed with $40 \%$ vegetable wastes silage is $21.05 \%$.

\section{Ash Content}

The average ash content in this research is 0.15 to $0.69 \%$. Moreover, the result of statistical analysis showed that there is no significant effect of feed types and feeding time to the ash content in Garut lamb. The finding in this research is lower than Purbowati and Suryanto (2002) which showed the ash content in lamb is at 2-3\%, and Suparno et al. (2009) at 1.009 to $1.403 \%$. Aberle et al. (2001) added that ash content in lamb is around $1.5 \%$.

Overall, the ash content in lamb is relatively constant and smaller compared to other chemical compounds. The similar result is also shown by Purbowati et al. (2010) with ash makes up the smallest chemical content in lamb. The ash content indicates inorganic minerals in food, and the commonly found mineral in lamb include calcium, iron, magnesium, potassium, sulfur, phosphorus, sodium and chlorine (Aberle et al., 2001).

\section{CONCLUSION}

The water, fat, protein and ash content in Garut lamb fed with BSW were relatively similar to the fed with forage (both consisted of 14\% isoprotein and 65\% iso-TDN). Moreover, the different feeding time did not show significant differences as well, and no interaction was found between feed types and feeding time to the lamb chemical composition.

\section{ACKNOWLEDGMENT}

The research was carried out by the support of Hibah Penelitian Unggulan Strategis Perguruan Tinggi research fund granted for Dr. Ir. Moh. Yamin, MAgr.Sc. 


\section{REFFERENCES}

Assosiation of Official Analytical Chemists. (2005). Official Method of Analysis. Washington DC: Benyamin Franklin Station.

Astuti, D. A., Baba, A. S., and Wibawan, I. W. T. (2011). Rumen fermentation, blood metabolites, and performance of sheep fed tropical browse plants. Media Peternakan, 34(3), 201-206. https://doi.org/10.5398/medpet.2011. 34.3.201

Cloete, J. J. E., Hoffman, L. C., Claasen, B., and Cloete, S. W. P. (2012). Effect of production system on the growth rate, carcass characteristics and carcass composition of Dorper lambs. Livestock Research for Rural Development, 24(6), 8.

Directorate General of Livestock and Animal Health of Indonesia. (2012). Statsitik Peternakan dan Kesehatan Hewan. Jakarta: Dirjen PKH.

Falahudin, A., and Imanudin, O. (2019). Kualitas daging domba yang diberi pakan silase limbah sayuran. Jurnal Ilmiah Peternakan Terpadu, 6(3), 146. https://doi.org/10.23960/jipt.v6i 3.p140-146

Forbes, J., and Mayes, R. (2002). Food Choice. In: Sheep Nutrition,. (M. Freer and H. Dove, Eds.). Australia: CABI and CSIRO publishing.

Ifafah, W. W., Rahayu, S., Diapari, D., and Baihaqi, M. (2011). The Utilization Of Bean Sprout Waste As A Sheep Feed In Order To Reduce Waste Pollution In Indonesian Traditional Market. In Proceedings of the 18th Tri-University International Joint Seminar dan Symposium (pp. 1-4). Jiangshu University.

Mattjik, A., and Sumertajaya, I. M. (2006). Perancangan Percobaan Dengan Aplikasi SAS dan MINITAB. In Perancangan percobaan dengan aplikasi SAS dan MINITAB (p. 211).

Purbowati, E., Hasanah, U., Adiwinarti, R.,
Sutrisno, C., Baliarti, E., Budhi, S. P., and Lestariana. (2010). Effect Of Complete Feed From Various Agricultural And Agroindusties ByProduct On Chemical Composition Of Local Mutton. In Paper presented at National Seminar of Animal Husbandry and Veterinary Technology (pp. 537-543). Bogor: Indonesia.

Purbowati, E., Hasanah, U., Adiwinarti, R., Sutrisno, C., Baliarti, E., Budhi, S. P., and Lestariana. (2006). Chemical composition of longissimus dorsi and biceps femoris on different slaughter weight of local male sheep reared in the village. Jurnal Animal Production, 8(1), 1-7.

Purbowati, E., and Suryanto, E. (2000). Komposisi kimia otot Longissimus dorsi dan Biceps femoris domba yang diberi pakan dasar jerami padi dan aras konsentrat yang berbeda. Jurnal Pengembangan Peternakan Tropis, 25(2), 66-72.

Rahayu, S., Yamin, M., Sumantri, C., and Astuti, D. A. (2016). Growth performance and physiological responses of garut lambs fed diets mung bean sprout waste at different times. Pakistan Journal of Nutrition, 15(1), 80-84. https://doi.org/10.3923/ pjn.2016.80.84

Saenab, A., and Retnani, Y. (2011). Beberapa model teknologi pengolahan limbah sayuran pasar sebagai pakan alternatif pada ternak (kambing/domba) di perkotaan. In National Workshop of Small Ruminants Diversification.

Soeparno. (2005). Ilmu dan Teknologi Daging (4th ed.). Yogyakarta: Gadjah Mada University Press.

Suparno, A., Rukmi, A. A., Adiwinarti, R., Purbowati, E., Arifin, M., and Mawati, S. (2009). The Effect Of Crude Protein And Energy Ratio On The Chemical Composition And Physical Quality Of Meat In Local 
Sheep. In Paper presented at National Seminar of Animal Husbandry and Veterinary Technology (pp. 399405). Bogor.

Suprayogi, A., and Astuti, D. (2005). Physiological status Of Indoor Sheep In The Tropical Rain Forest (HPGW) Environment. In Paper presented at Mini Workshop of Southeast Asia Germany Alumni Network (SEAG) (pp. 1-5). Bogor.

Tillman, A., Hartadi, H., Reksohadiprojo, S., Prawirokusumo, S., and Lebdosoekojo, S. (1998). Ilmu Makanan Ternak Dasar. Yogyakarta: Gajah Mada University Press.
Yani, A., and Purwanto, B. (2006). Pengaruh Iklim Mikro terhadap Respons Fisiologis Sapi Peranakan Fries Holland dan Modifikasi Lingkungan untuk Meningkatkan Produktivitasnya (ULASAN). Media Peternakan, 29(1), 35-46.

Yousef, M. (1985). Stress Physiology in Livestock: Basic Principle. Boca Ralton: CRC press. 